\title{
Downregulation of CD94/NKG2A inhibitory receptors on CD8+ T cells in HIV infection is more pronounced in subjects with detected viral load than in their aviraemic counterparts
}

Mustapha Zeddou ${ }^{1}$, Souad Rahmouni*1, Arnaud Vandamme ${ }^{1}$, Nathalie Jacobs' ${ }^{2}$, Frédéric Frippiat ${ }^{3}$, Philippe Leonard ${ }^{3}$, Nicole SchaafLafontaine ${ }^{4}$, Dolores Vaira ${ }^{3}$, Jacques Boniver ${ }^{2}$ and Michel Moutschen ${ }^{1,3}$

Address: ${ }^{1}$ University of Liège, Laboratory of Immunology and Infectious Diseases, GIGA-R, Liège, Belgium, ${ }^{2}$ University of Liège, Department of Pathology, CRCE-GIGA, Liège, Belgium, ${ }^{3}$ University of Liège, Department of Infectious Diseases, CHU, Liège, Belgium and ${ }^{4}$ University of Liège, Department of Biological Haematology, CHU, Liège, Belgium

Email: Mustapha Zeddou - mzeddou@ulg.ac.be; Souad Rahmouni* - srahmouni@ulg.ac.be;

Arnaud Vandamme - Arnaud.Vandamme@student.ulg.ac.be; Nathalie Jacobs - n.jacobs@ulg.ac.be; Frédéric Frippiat - f.frippiat@chu.ulg.ac.be; Philippe Leonard - philippe.leonard@chu.ulg.ac.be; Nicole Schaaf-Lafontaine - nicole.schaaf@chu.ulg.ac.be;

Dolores Vaira - dvaira@chu.ulg.ac.be; Jacques Boniver - J.Boniver@ulg.ac.be; Michel Moutschen - michel.moutschen@ulg.ac.be

* Corresponding author

Published: 10 October 2007

Retrovirology 2007, 4:72 doi:10.1186/1742-4690-4-72

This article is available from: http://www.retrovirology.com/content/4/I/72

(C) 2007 Zeddou et al; licensee BioMed Central Ltd.

This is an Open Access article distributed under the terms of the Creative Commons Attribution License (http://creativecommons.org/licenses/by/2.0), which permits unrestricted use, distribution, and reproduction in any medium, provided the original work is properly cited.
Received: 2 April 2007

Accepted: 10 October 2007

\begin{abstract}
The CD94/NKG2A heterodimer is a natural killer receptor (NKR), which inhibits cell-mediated cytotoxicity upon interaction with MHC class I gene products. It is expressed by NK cells and by a small fraction of activated $C D 8^{+} \mathrm{T}$ lymphocytes. Abnormal upregulation of the CD94/NKG2A inhibitory NKR on cytotoxic $T$ cells (CTLs) could be responsible for a failure of immunosurveillance in cancer or HIV infection. In this study, CD94/NKG2A receptor expression on $\mathrm{CD}^{+} \mathrm{T}$ lymphocytes and NK cells was assessed in $46 \mathrm{HIV}$ - I-infected patients (24 viraemic, 22 aviraemic) and 10 healthy volunteers. The percentage of $C D 8^{+} \mathrm{T}$ lymphocytes expressing the CD94/NKG2A inhibitory heterodimer was very significantly decreased in HIV-I-infected patients in comparison with non-infected controls. Within the HIV infected patients, the proportion of $\mathrm{CD}^{+} \mathrm{T}$ lymphocytes and NK cells expressing CD94/NKG2A was higher in subjects with undetectable viral loads in comparison with their viraemic counterparts. No significant difference was detected in the proportion of $\mathrm{CD} 8^{+} \mathrm{T}$ lymphocytes expressing the activatory $\mathrm{CD} 94 / \mathrm{NKG} 2 \mathrm{C}$ heterodimer between the HIV-I infected patients and the healthy donors, nor between the vireamic and avireamic HIV-I infected patients. In conclusion, chronic stimulation with HIV antigens in viraemic patients leads to a decreased rather than increased CD94/NKG2A expression on CD8 ${ }^{+}$ T lymphocytes and NK cells.
\end{abstract}




\section{Findings}

The CD94/NKG2 heterodimer is a C-type lectin receptor, formed by the covalent association of CD94, a protein with a short non-signaling intracytoplasmic tail [1], and one of the NKG2 molecules. To generate a functional receptor, CD94 is disulfide linked with a member of the NKG2 family, namely NKG2A, -B, -C or -E [2,3]. In humans, CD94/NKG2A interacts with complexes of non-classical HLA-E molecules [4,5]. The intracellular domain of NKG2A contains immunoreceptor tyrosine-based inhibition motifs (ITIMs), responsible for transducing inhibitory signals [6]. The other NKG2 members lack ITIMs and are linked to transmembrane proteins, such as DAP10 and DAP12 which contain immunoreceptor tyrosine-based activating motifs and transduce activating signals [7]. CD94/ NKG2A is normally expressed on most NK cells and on a small fraction of $\mathrm{CD} 8^{+} \mathrm{T}$ lymphocytes. The proportion of NK cells bearing the CD94/NKG2A inhibitory receptor decreases in advanced HIV infection [8], in contrast with other inhibitory receptors of the KIR family which are upregulated. It is presently unknown if HIV infection has similar effects on the expression of the CD94/ NKG2A inhibitory receptor by CD8 ${ }^{+} \mathrm{T}$ cells. A few studies have shown that CD94 expression by CD8+ T cells is increased during HIV infection [9-11] and have led to postulate that increased expression of the CD94/ NKG2A inhibitory receptors is one of the mechanisms rendering $\mathrm{HIV}$-specific $\mathrm{CD} 8^{+} \mathrm{T}$ lymphocytes unable to control HIV-1 infection [12]. Nevertheless, the simultaneous expression of both subunits of the inhibitory receptor on CD8 ${ }^{+} \mathrm{T}$ cells has hardly been studied in HIV infection. Costa et al. using two-color FACS analysis to study $\mathrm{CD}^{+}{ }^{+} \mathrm{NKG}_{2} \mathrm{~A}^{+} \mathrm{T}$ cells, showed no difference between uninfected controls, long term non progressors or aviraemic subjects under HAART. A slight increase was noted in subjects with active viral replication [13], in contradiction with the downregulation previously observed on NK cells from infected subjects.

In the present study, we used four-colour FACS to investigate the expression of CD94/NKG2A and CD94/ NKG2C on $\mathrm{CD}^{+}{ }^{+} \mathrm{CD} 8{ }^{+} \mathrm{T}$ lymphocytes and NK cells from HIV-1 infected patients, and its relationship with HIV-1 viraemia. Immunostaining was performed with fluorochrome-conjugated antibodies in $100 \mu \mathrm{l}$ of peripheral blood from HIV-1 infected patients. Participants included $46 \mathrm{HIV}-1$ infected patients (23 viraemic and 23 aviraemic) and 10 healthy age-matched controls. The cells were analyzed on FACSvantage with CellQuest software (BD Biosciences). Flow Cytometry analysis was performed using fluorescence-conjugated antibodies to CD3, CD8, CD56, CD94, NKG2A and NKG2C. The Mann-Whitney test was used to compare the proportion of cells expressing each heterodimer between the three different groups of subjects (i.e. HIV infected viraemic, aviraemic and non infected controls). Figure 1 ( $1 \mathrm{~A}, 1 \mathrm{~B}$ and $1 \mathrm{C}$ ) shows a representative dot plot of the CD94/NKG2A expression by $\mathrm{CD} 8{ }^{+} \mathrm{T}$ lymphocytes and NK cells from healthy and HIV-1 infected controls (viraemic and aviraemic). There was a dramatic decline in the proportion of $\mathrm{CD}^{+} \mathrm{T}$ cells expressing the CD94/NKG2A heterodimer in HIVinfected patients in comparison with uninfected controls (mean \pm SEM, $4.91 \pm 0.49 \% \mathrm{n}=46$ vs. $17.93 \pm$ $3.26 \% \mathrm{n}=10 \mathrm{p}<0.0001$ ) (Figure 1D). Interestingly, the decrease of CD94/NKG2A expression was more pronounced in patients with detected viral load than in patients with less than 50 copies/ml (mean \pm SEM, 4.15 $\pm 0.65 \% \mathrm{n}=23$ vs. $5.68 \pm 0.7190 \mathrm{n}=23 ; \mathrm{p}=0.0379)$. Similarly, the proportion of CD8+ T cells expressing the CD94/NKG2C was lower in HIV infected patients than in controls but the difference was not statistically significant (mean \pm SEM, $1.73 \pm 0.59 \% \mathrm{n}=16$ vs. $5.45 \pm$ $2.25 \% \mathrm{n}=10, \mathrm{p}=0.1626$ ) (data not shown).

In HIV infected patients, there was a weak but significant correlation between the proportion of $\mathrm{CD}^{+} \mathrm{T}$ lymphocytes and NK cells expressing the CD94/NKG2A heterodimer $\left(\mathrm{r}^{2}=0,09184 ; \mathrm{p}=0.0406\right)$ and the proportion of NK cells expressing the inhibitory receptor tended to be lower in viraemic patients than in subjects with less than 50 copies/ml. (mean \pm SEM, $43.11 \pm 5.67 \%$ vs. $56.05 \pm$ $4.67 \%$; $=0.019$ ). There was no correlation of the expression of the inhibitory receptor with absolute or relative CD4 counts (data not shown).

In summary, we observed a downregulation of CD94/ NKG2A on $\mathrm{CD}^{+} \mathrm{T}$ cells in HIV infection, in accordance with what was previously described for NK cells. The mechanisms linking viral replication with downregulation of the inhibitory CD94/NKG2A receptor remains obscure. Upregulation of CD94/NKG2A has previously been observed in various animal models of viral and bacterial infections [14] and in chronic antigenic stimulation [15]. Loss of CD94/NKG2A might correspond to the terminal differentiation which occurs in a large fraction of $\mathrm{CD}^{+} \mathrm{T}$ cells during HIV infection. Indeed, recent observations made in an experimental model of persistent polyoma virus infections suggest that CD94/ NKG2A CD8+T lymphocytes might constitute a less differentiated subset of CD8 ${ }^{+} \mathrm{T}$ cells and maintain a higher proliferative potential and capacity to secrete IL-2 [16]. Whatever is the mechanism involved, the loss of CD94/ NKG2A in HIV infection could also contribute to the polyclonal activation which characterizes HIV infection. 

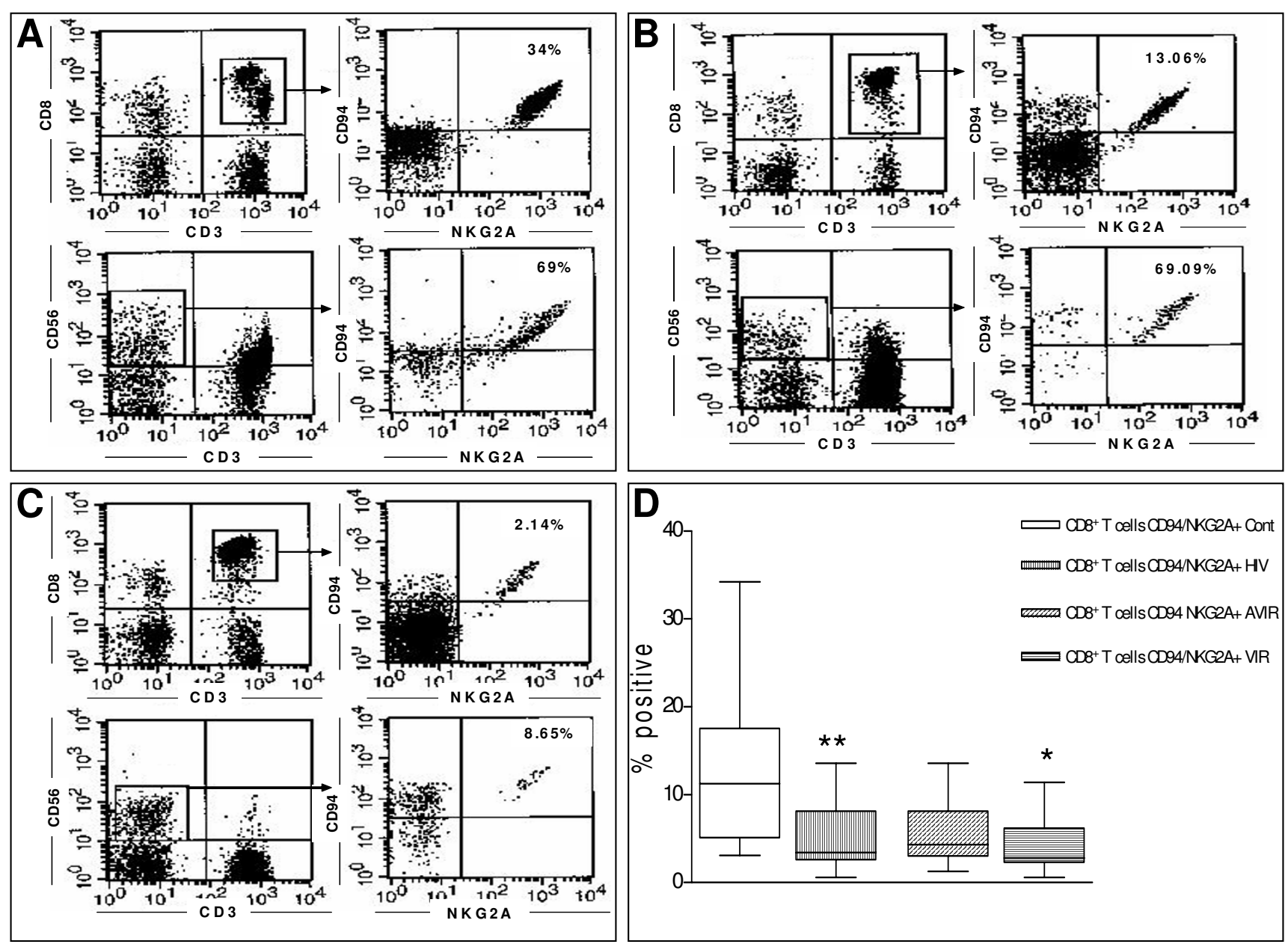

Figure I

CD94/NKG2A expression in CD8+ T lymphocytes and NK cells from healthy donors and HIV-I infected patients. Flow cytometry analysis was performed on $100 \mu \mathrm{l}$ of peripheral blood from A: healthy controls, B: avireamic HIV-I infected patients, C: vireamic HIV infected patient, using fluorescent conjugated antibodies to CD3, CD8, CD56, CD94, and NKG2A. Analysis was performed on gated cells. D: Comparison of CD94/NKG2A expression in CD8 ${ }^{+} \mathrm{T}$ lymphocytes from healthy controls (open bar; $n=10$ ), HIV-I infected patients (vertical hatched bar; $n=46$ ), avireamic HIV-I infected patients (oblique hatched bar; $n=$ 23) and vireamic HIV-I infected patients (horizontal hatched bar; $n=23$ ). Data represent the mean \pm SEM of each group. The Mann-Whitney test was used to calculate significant differences between the different groups. $* * p<0,0$ I significance of difference of CD94/NKG2A expression in CD8 ${ }^{+}$T cells between healthy controls vs HIV-I infected patients; * $<0,05$ significance of difference of CD94/NKG2A expression in CD8 ${ }^{+} \mathrm{T}$ cells between HIV-I infected avireamic patients vs vireamic patients.

\section{Acknowledgements}

This work was supported by the Fond National de la Recherche Scientifique (FNRS), the Centre anticancéreux près I'Université de Liège (CAC) and a grant from the Walloon Region.

\section{References}

I. Chang CA, Rodriguez M, Carretero M, Lopez-Botet JH, Phillips , Lanier LL: Molecular characterization of human CD94: a type II membrane glycoprotein related to the C-type lectin superfamily. Eur J Immunol 1995, 25:2433-2437.

2. Brooks AG, Posch PE, Scorzelli C], Borrego F, Coligan JE: NKG2A complexed with CD94 defines a novel inhibitory natural killer cell receptor. J Exp Med 1997, 185:795-800.
3. Carretero M, Cantoni C, Bellon T, Bottino C, Biassoni R, Rodriguez A, Perez-Villar JJ, Moretta L, Moretta A, Lopez-Botet M: The CD94 and NKG2-A C-type lectins covalently assemble to form a natural killer cell inhibitory receptor for HLA class I molecules. Eur J Immunol 1997, 27:563-567.

4. Brooks AG, Borrego F, Posch PE, Patamawenu A, Scorzelli CJ, Ulbrecht M, Weiss EH, Coligan JE: Specific recognition of HLA-E, but not classical, HLA class I molecules by soluble CD94/NKG2A and NK cells. J Immunol I999, I62(I):305-3I3.

5. Lee N, Llano M, Carretero M, Ishitani A, Navarro F, Lopez-Botet M, Geraghty DE: HLA-E is a major ligand for the natural killer inhibitory receptor CD94/NKG2A. Proc Natl Acad Sci USA 1998, 95:5199-5204.

6. Kabat J, Borrego F, Brooks A, Coligan JE: Role that each NKG2A immunoreceptor tyrosine-based inhibitory motif plays in 
mediating the human CD94/NKG2A inhibitory signal. J Immunol 2002, 169:1948-1958.

7. Lanier LL, Corliss B, Wu J, Phillips JH: Association of DAP I 2 with activating CD94/NKG2C NK cell receptors. Immunity 1998, 8:693-701.

8. Mavilio D, Benjamin J, Daucher M, Lombardo G, Kottilil S, Planta MA, Marcenaro E, Bottino C, Moretta L, Moretta A, Fauci AS: Natural killer cells in HIV-I infection: dichotomous effects of viremia on inhibitory and activating receptors and their functional correlates. Proc Natl Acad Sci USA 2003, 100: I50 I I- 15016.

9. Galiani MD, Aguado E, Tarazona R, Romero P, Molina I, Santamaria $M$, Solana R, Pena J: Expression of killer inhibitory receptors on cytotoxic cells from HIV-I-infected individuals. Clin Exp Immunol 1999, I I 5:472-476.

10. Tarazona R, DelaRosa O, Casado JG, Torre-Cisneros J, Villanueva JL, Galiani MD, Pena J, Solana R: NK-associated receptors on CD8 T cells from treatment-naive HIV-infected individuals: defective expression of CD56. AIDS 2002, I6:197-200.

II. Wesch D, Kabelitz D: Differential expression of natural killer receptors on Vdeltal gammadelta $\mathrm{T}$ cells in HIV-I-infected individuals. J Acquir Immune Defic Syndr 2003, 33:420-425.

12. Moser JM, Byers AM, Lukacher AE: NK cell receptors in antiviral immunity. Curr Opin Immunol 2002, I 4:509-5I6.

13. Costa P, Rusconi S, Fogli M, Mavilio D, Murdaca G, Puppo F, Mingari MC, Galli M, Moretta L, De MA: Low expression of inhibitory natural killer receptors in CD8 cytotoxic $T$ lymphocytes in long-term non-progressor HIV-I-infected patients. AIDS 2003, 17:257-260.

14. McMahon CW, Zajac AJ, Jamieson AM, Corral L, Hammer GE, Ahmed R, Raulet DH: Viral and bacterial infections induce expression of multiple NK cell receptors in responding CD8(+) T cells. J Immunol 2002, I69: I444-I452.

15. Thimme R, Appay V, Koschella M, Panther E, Roth E, Hislop AD, Rickinson $A B$, Rowland-Jones SL, Blum HE, Pircher $H$ : Increased expression of the NK cell receptor KLRG I by virus-specific CD8 T cells during persistent antigen stimulation. J Virol 2005, 79:12112-12116.

16. Byers AM, Andrews NP, Lukacher AE: CD94/NKG2A expression is associated with proliferative potential of CD8 T cells during persistent polyoma virus infection. J Immunol 2006, I76:6121-6129.

Publish with Bio Med Central and every scientist can read your work free of charge

"BioMed Central will be the most significant development for disseminating the results of biomedical research in our lifetime. "

Sir Paul Nurse, Cancer Research UK

Your research papers will be:

- available free of charge to the entire biomedical community

- peer reviewed and published immediately upon acceptance

- cited in PubMed and archived on PubMed Central

- yours - you keep the copyright

Submit your manuscript here:

http://www.biomedcentral.com/info/publishing_adv.asp
BioMedcentral 